\title{
Exploration of the Factors of Work Readiness during the Pandemic COVID-19
}

\section{Eksplorasi Faktor Kesiapan Kerja selama Pandemi COVID-19}

\author{
Laili Qomariyah $^{1}$, Mariza Ningtyas Febriyanti ${ }^{2}$
}

${ }^{1,2}$ Universitas Muhammadiyah Magelang, Indonesia

\begin{tabular}{l} 
ARTICLE INFO \\
\hline Article history: \\
DOI: \\
10.30595/pssh.v2i.121
\end{tabular}

Submitted: July 02, 2021

Accepted: Aug 25, 2021

Published: Sept 24, 2021

Keywords:

Work readiness, fresh graduates, internal forces, social support, competency

\begin{abstract}
This study aims to develop a work readiness theory during pandemics based on existing theories and data obtained in the field. The research approach used is a qualitative method with a grounded theory approach. Research subjects are parties who have an interest and are involved in job readiness, namely managers, employees, recruiters, and educators. There are fifteen subjects in this research. Data analysis was carried out in 4 stages: open coding, focused coding, axial coding, and selective coding to organize and integrate categories into a single category. Validation of this study was carried out by triangulation, namely by validating respondents. The researcher re-interviewed the participants by questioning the results of previous interviews to see the consistency of the data obtained. The results showed that five factors correlate with each other. The first is social support which includes support from the school environment, parents, and friendship. The second factor is the internal force which functions as a driving force for individuals to carry out a behavior. The third is the opportunity aspect. The fourth is the competency that includes how to work attitude of fresh graduates and their digital mindset. Individuals are ready to work if competence and persistence in the search can be carried out correctly. And the last selection readiness is about readiness to understand their position. This research is expected to become additional information for the future as an initial source in developing studies related to the work readiness of graduates. The study results show that it takes both internal and external strength to prepare fresh graduates for work.
\end{abstract}

This work is licensed under a $\underline{\text { Creative Commons Attribution } 4.0 \text { International License. }}$

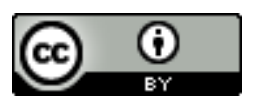

\section{Corresponding Author:}

Laili Qomariyah

Universitas Muhammadiyah Magelang, Indonesia

Email: laili.qomariyah@ummgl.ac.id

\section{INTRODUCTION}

Statistical data shows that the current unemployment rate is predicted to rise sharply. This prediction refers to the composition of the workforce based on the classification of the economic sector, type of business, and duration of working hours. From this composition, the crisis with simultaneous characteristics can increase open unemployment by 3.5 million to 8.5 million people throughout 2020 . This means that the unemployment rate has the potential to grow from the current range of 5.2 percent to 5.3 percent between 7.7 percent on the moderate scale and 10.3 percent on the severe scale (Jalil, M, \& Kasnelly, 2020).

This condition seems to contradict the many existing job opportunities, one of which is the MEA policy. With the enactment of the MEA, the ASEAN region has become a free market where there is a free flow of goods, services, investment, capital, and skilled labor. MEA can be a gateway and open opportunities for Indonesian workers to work in other countries, both in the ASEAN region and outside the ASEAN region (Wirianata, 2017). This indicates that there will be a higher employment absorption. MEA also shows that there will be many great opportunities for Indonesian people to find work in Indonesia and the ASEAN region to improve the welfare of the Indonesian people. But unfortunately, the MEA does not seem to have any effect on job seekers. Various causes of unemployment identify the difficulty of finding work. Changes in work patterns, activities, and the company's perspective are an afterthought to becoming quality human resources, especially during the pandemic. This requires every job seeker to have mature job readiness.

Various extreme changes have occurred since the pandemic has rapidly entered various countries in the last 
two years. Every change that is happening today seems to support digital development and progress. This is evidenced by the publication of the Circular letter Dinas Tenaga Kerja, Transmigrasi dan Energi Provinsi DKI Jakarta (14/SE/2020 Tahun 2020) about the appeal of work from home. The existence of work from home (WFH) rules during the Covid-19 outbreak can be related to the provisions (Pasal 86 ayat (1) huruf a Undang-Undang Nomor 13 Tahun 2003) about employment ("UU Ketenagakerjaan) (Aurelia Oktavira S.H, 2020). This has resulted in various jobs done directly in the office, now starting to be done online through digital media intermediaries, often known as work from home (WFH). Working at home or the WFH concept is carried out to break the chain of the Covid-19 virus so that all circles of society must comply. The community's compliance with WFH's work orders certainly has a problematic impact on job seekers. During this pandemic, not many companies have opened job vacancies. Only a few divisions have job openings. Job seekers, including fresh graduates, also experience obstacles in finding work during this pandemic (Nadella \& Rahadi, 2020). The COVID-19 pandemic has added to the unemployment problem in Indonesia, where the main problem is the low work readiness of fresh graduates in Indonesia.

Work readiness has the skills and abilities that can ensure employability and enable success in the workplace (Makki, Javaid, \& Bano, 2016). Meanwhile, according to Clark (2013), job readiness is an essential skill for training and success in the workplace. This skill is fundamental because it relates to the competence of workers who support the company's progress. According to Prikshat et al. (2019), various terms are used to allude to specific skills, knowledge, and attributes that contribute to workability, namely key competencies and graduation. The time is considered that graduates who are ready to work have competence for industrial sustainability and high productivity in conditions of global competition.

Many researchers have research work readiness. The results show that work readiness can be increased through formal education (Jollands, Jolly, \& Molyneaux, 2012). Other studies related to work readiness have also been carried out to develop the work-readiness measurement scales (Caballero, C., Walker, A., \& FullerTyszkiewicz, 2011; Verma, Sanjeev, \& Alan, 2019). On the other hand, methods to assess the work readiness of fresh graduates in the context of recruitment and selection have also been investigated (Caballero \& Walker, 2010). However, researchers see that there is still no research related to the work readiness of fresh graduates during the COVID-19 pandemic. Based on this explanation, this study wants to explore the work readiness of new graduates during the pandemic from the stakeholder's point of view to understand the essential point of fresh graduates' work readiness.

\section{THEORITICAL FRAMEWORK}

\section{Work Readiness}

Work readiness is a concept that needs to be continuously developed to ensure that work readiness can always answer the needs of the world of work. Work readiness is an indicator that can predict a person's success in the world of work in the future (Caballero, C., Walker, A., \& Fuller-Tyszkiewicz, 2011; Caballero \& Walker, 2010). Work readiness is dynamic along with the times. This is due to the demands that keep changing from employer to employee. Employers want employees to have a positive attitude towards the company (Walker \& Campbell, 2013). A positive work attitude can improve individual performance, indirectly improving company performance (Kaplan $\&$ Kaplan, 2018). This is the reason why companies want prospective employees who are ready to work. Employers don't want to waste a lot of their time educating new employees. They prefer prospective employees who are prepared to perform. However, currently, there are still many fresh graduates who have high academic output but have not been able to change the mindset from students to workers, so that they are not ready to enter the world of work.

\section{Fresh Graduates}

The world of work is very familiar with new graduates or fresh graduates looking for a job. Recent graduates suffer from economic crises in most countries and feel less integrated into society (Serhan, Tsangari, Bengoa, \& Mekdessi, 2015). They have difficulty finding work, the complexity of job integration, and difficulty finding housing. In a complex economic environment, recent graduates are not only academically proficient. Still, they must also be prepared with the necessary personal attributes to enhance their ability to enter the world of work (Krishnan, Ramalingam, Ching, \& Maruthai, 2017). Competence refers to the visible elements and characteristics they possess (such as attitudes, traits, and motives) (Boyatzis, 1982) that promote superior job performance (Pang, Wong, Leung, \& Coombes, 2019). Competence can also describe what people know, what they can do, and what they want to do.

3. The things that are seen to affect three psychological states. This theory states that employees who experience a high level of psychological well-being (experiencing the meaning of work, experiencing responsibility for work outcomes, and knowing the actual results of work activities) tend to feel good about themselves and respond positively to their work. Therefore, new graduates must have good competencies and characteristics to be able to work well. Not only that, but recent graduates must also be able to adapt to work or those adapted to careers. According to Savickas (in Bt Mohammad et al., 2020), adaptability can be ascertained as readiness to accept or handle jobs that are predicted to be given by the company and participate in all the work to be done and how they manage changing working conditions. 


\section{RESEARCH METHODOLOGY}

This study used a qualitative method with a grounded theory approach, a systematic research approach to find a theory through data collection and analysis (Engward, 2013). Researchers build theories or concepts from empirical data, a social process that occurs in the interaction of human behavior. The theory generated from this research is an abstract analytic schema of a phenomenon (competencies required in work readiness during a pandemic) related to the current situation.

\section{Participants}

Participants in this study amounted to 15 people interested in the work readiness of fresh graduates. Participants consisted of managers $(n=2)$ who had held managerial positions for more than five years, employees $(n=6)$ who had more than three years, recruiters/industrial psychologists, and organizations $(n=5)$ who had worked as recruiters for more than five years. Of five years and lecturers $(n=2)$ who have more than five years of teaching experience. The sampling technique used purposive sampling based on the consideration that the participants were people who had a lot of information (Strauss \& Corbin, 1997).

\section{Procedure}

This research is the first step of a study conducted by researchers related to investigating the work readiness of fresh graduates. The primary research stages will go through several stages from initial research to see what kind of work readiness employers need for new graduates. Finally, the primary research will create an intervention program that can increase the work readiness of fresh graduates following current work demands.

\section{Data Collection}

Data collection was carried out by in-depth interviews with participants online using recorded communication media to find saturated data. The research was conducted from May 2021 to June 2021.

This study begins by exploring general questions related to the work readiness of participants. Furthermore, the researchers designed new open-ended questions to dig deeper into work readiness during the pandemic (Charmaz, 2006). The questions given to participants have topics related to work readiness but with slightly different questions between participants with different positions. This is intended so that exploration can be carried out from various position points of view. The topic of questions that the researcher gave to the participants included several things, including 1) what abilities are companies looking for in employees during this pandemic? 2) what work demands do employees receive from employers during the pandemic, and how are they different from before the pandemic?

\section{Analysis Strategy}

Data analysis was carried out in 4 stages, namely: 1) open coding to generate categories from empirical data, 2) focused coding used to synthesize categories, 3) axial coding to find relationships between categories, and 4) selective coding to organize and integrate categories. Into one category, and understand emerging patterns (Charmaz, 2006; Strauss \& Corbin, 1997). The validation of this study was done by triangulation, namely by validating the respondents. The researcher re-interviewed the participants by asking the results of previous interviews to see the consistency of the data obtained.

\section{RESULTS AND DISCUSSION}

Data collection was done by interviewing all participants. Ten participants were interviewed using online interviews, namely through telecommunication channels, and 5 participants were interviewed offline. The demographics of the participants are shown in table 1.

Participants Profile

Table 1. Participant's profile

\begin{tabular}{ccccc}
\hline Number of & Sex & Age & Position & Length of work \\
\hline
\end{tabular}

Proceedings homepage: https://conferenceproceedings.ump.ac.id/index.php/pssh/issue/view/7 


\begin{tabular}{|c|c|c|c|c|}
\hline Participants & & year) & & \\
\hline Participant 1 & Male & 45 & Manager & 16 years \\
\hline Participant 2 & Male & 35 & Manager & 5 years \\
\hline Participant 3 & Male & 25 & Employee & Two years \\
\hline Participant 4 & Female & 29 & Employee & Two years \\
\hline Participant 5 & Male & 30 & Employee & Three years \\
\hline Participant 6 & Female & 31 & Employee & Three years \\
\hline Participant 7 & Female & 37 & Employee & Three years \\
\hline Participant 8 & Male & 45 & Employee & 20 years \\
\hline Participant 9 & Female & 37 & PIO & 6 years \\
\hline Participant 10 & Female & 30 & PIO & Seven years \\
\hline Participant 11 & Female & 33 & $\mathrm{PIO}$ & Six years \\
\hline Participant 12 & Female & 33 & PIO & 5 years \\
\hline Participant 13 & Female & 32 & PIO & 5 years \\
\hline Participant 14 & Female & 27 & Teacher & Three years \\
\hline Participant 15 & Female & 36 & Lecturer & 3 years \\
\hline
\end{tabular}

\section{Discussion}

Based on the relationship between categories, the researcher arranged sub-categories, types, and core categories. The description of the research findings is described in table 2.

Table 2. Result

\begin{tabular}{|c|c|c|}
\hline Core Category & Category & Sub Category \\
\hline \multirow[t]{6}{*}{ Social support } & \multirow[t]{2}{*}{ Family } & Encouragement \\
\hline & & Studying expenses \\
\hline & \multirow[t]{2}{*}{ Educational environment } & Soft skill \\
\hline & & Hard skill \\
\hline & \multirow[t]{2}{*}{ Peers } & Sharing information \\
\hline & & Togetherness \\
\hline \multirow[t]{8}{*}{ Internal Forces } & \multirow[t]{2}{*}{ Struggle } & Information seeking \\
\hline & & Best effort for trying \\
\hline & \multirow[t]{3}{*}{ Continuous learning } & Want to learn \\
\hline & & Self-development \\
\hline & & Open-minded \\
\hline & \multirow[t]{3}{*}{ Personality } & Lack of initiative \\
\hline & & Lack of motivation \\
\hline & & Passive \\
\hline \multirow[t]{7}{*}{ Opportunity } & \multirow[t]{4}{*}{ Job experience } & internship \\
\hline & & part-time \\
\hline & & side job \\
\hline & & Volunteer \\
\hline & \multirow[t]{3}{*}{ Study experience } & Finding the new knowledge \\
\hline & & Course \\
\hline & & Explore the environment \\
\hline \multirow[t]{6}{*}{ Competency } & \multirow[t]{4}{*}{ Work Attitude } & Creativity \\
\hline & & Communication skill \\
\hline & & Adaptive \\
\hline & & Commitment \\
\hline & \multirow[t]{2}{*}{ Digital mindset } & Flexible time \\
\hline & & Work with device \\
\hline \multirow[t]{2}{*}{ Selection readiness } & \multirow[t]{2}{*}{ Understanding about jobs } & Knowing about working situation \\
\hline & & Readiness to interview \\
\hline
\end{tabular}

Social support

Support from the environment is needed and affects individuals related to their work readiness. Individuals can become more ready to work when they get help from their families, especially parents. Encouragement from parents to children to be more ready to work includes support in directing their education and career (Purnawan, 
Santosa, \& Kurniawan, 2020). In addition, financial support in self-development also contributes to individual work readiness. In addition, peers and the educational environment can foster personal enthusiasm in preparing themselves for the world of work. The manifestation of how peers interact for increasing work readiness is by sharing information related to job vacancies, jointly applying for jobs, looking for the job, and feeling like comrades. Other social support also comes from the educational environment. Hard skills and soft skills need to be given to individuals when they are still students. Fresh graduates who get adequate soft and hard skills can quickly complete their work when accepted. They will become more aware of how to get the job done. Fresh graduates who have deficient soft skills and hard skills will find it difficult to complete work in their workplace. That's because hard skills and soft skills are one of the main capitals in entering the world of work.

\section{Internal forces}

Internal forces. Internal forces are forces from within the individual that can encourage, influence, and do something. Individuals with a high fighting spirit of finding job vacancies have more significant opportunities than those who do not do their best (Halim, Jamilah, Adindo, \& Safaruddin, 2019). The following is a statement from participant 9 (psychologist) regarding how the internal force can form the work readiness of fresh graduates.

"Lulusan hari ini ketika ditanya apa yang telah mereka lakukan selama pencarian kerja mereka dapat dengan lantang menjawab melamar pekerjaan ... tetapi jika saya bertanya berapa banyak lowongan yang telah dilamar, mereka hanya dapat menyebutkan angka yang sangat kecil, ketika ditanya mereka mengisi hari-harinya dengan apa?.......mereka menjawab.......eeeehm menunggu lowongan" (wawancara 1,P9).

Graduates who show little effort in developing themselves and work hard to find work will find it challenging to be truly ready to enter the world of work. In addition, the individual's desire to continue developing will improve his ability to complete a job. Individuals who are open to something new reflect their potential in the workplace. Workplace conditions are dynamic and will continue to change. Without being open to new things, individuals will find it difficult to continue developing. The demand from the company is that individuals must be proactive and have the initiative to complete a job, be it their work or help the work of other coworkers.

\section{Opportunity}

High academic scores are not enough to prepare individuals to enter the world of work because they still need many experiences. Therefore, it is necessary to give individuals the opportunity to gain work experience and informal learning experiences to complement their formal education. Individuals who have the chance to study and work will have experiences related to the world of work. Opportunity doesn't come by itself. Opportunities must be pursued and sought because opportunities will only come if individuals try. The following participant, as a manager, shows his attitude by giving his argument about a chance.

"Kalau saya bilang kesempatan itu harus dicari bukan ditunggu sebelum memasuki dunia kerja mereka sudah harus memiliki pengalaman yang cukup. Banyak kok sebenarnya yang bisa mereka lakukan. Sejak masih kuliah sampai mereka mendapatkan pekerjaan mereka bisa melakukan hal-hal yang bisa meningkatkan soft skill dan hard skill mereka. Perusahaan tidak lagi mengajari mereka dari awal, karena yang perusahaan butuhkan adalah karyawan yang sudah siap bekerja." (Wawancara 2, P1).

Opportunities can come anytime and anywhere. It is not always interpreted as an opportunity for informal conditions.

\section{Competency}

The definition of competence is an individual's knowledge and skills that can support solving the problems being faced, especially in work. Competence is needed by someone so that it is easy to work (Mustikawanto, 2019). One of the competencies that are required during a pandemic is a digital mindset. Individuals who are not used to working with communication tools, electronic devices, and IT tools as support will create new problems. Individuals are required to be able to work from anywhere and anytime. Work time is very blurry. Individuals can work anytime, anywhere, and everything is like without any clear limitations related to time flexibility. This is because the company's demands are getting higher, so employees are needed who are ready at any time. In addition, it is not easy to change the habit of working with paper and switch to paperless. This is because changing habits to paperless requires good adaptation. Individuals who do not have a digital mindset will find it difficult to complete their work during the current pandemic. Another factor is work attitude. Work attitude is a behavior and a sense of liking or disliking something at work. The different work patterns between the pandemic and before the pandemic make companies want individuals ready to "run." Companies need individuals who are prepared to change. Work that can be done anywhere makes companies have to instill a commitment to their employees. Individuals who do not have a moral responsibility will find it difficult to conduct work not directly supervised by their superiors, namely work during WFH. In addition, virtual communication makes a lot of information distorted, so good communication skills can make individuals reduce these distortions. 


\section{Selection readiness}

Readiness in job selection is an assessment that is also taken into account. Individuals are considered not ready to work if they cannot convey well about themselves during an interview and selection (Caballero \& Walker, 2010). When selecting prospective employees, interviews and other tests are tools to photograph how the individual is, including his work readiness. How individuals react during selection is a reflection of individuals in the world of work. In addition, individuals who do not know the job description of the position they are applying for will make them lose their goals. It will work directionless. He will complete the work in front of him but cannot work more than is required because the individual has no plans to pursue it. Participant 13, as a psychologist, said about the condition of the candidate today.

"Banyak sekali calon karyawan yang saya wawancara melalui video call dan saya merasa mereka meremehkan......hm.... mungkin karena online dan mereka ada di rumah, sehingga mereka merasa ini bukan sesuatu yang formal. Saya sering lo menegur kandidiat saat wwancara......mas kok nggak sisiran? kalau mau merapikan rambut dulu saya persilahkan...... Sebenernya hal remeh itu saja bisa menunjukkan bagaimana keseriusan mereka dalam mencari kerja." (wawancara 1, P13).

Readiness in choosing a job will determine the assessment of how much work readiness a candidate has. Psychologists and managers will see that they cannot prepare well in simple matters, especially when they are faced with more complex and ambiguous issues.

\section{CONCLUSION}

This study indicates that the work readiness of fresh graduates during the COVID-19 pandemic has more complex aspects than work readiness before the pandemic. Social support, including family, peers, and educational environment, is essential for new graduates' job readiness. In addition, fresh graduates must have self-motivation and strength to prepare themselves for the world of work which is very different from the world of education. Opportunities that new graduates can capture can develop work readiness obtained through gaining experience and getting formal and informal education. The thing that cannot be obtained instantly in building work readiness is competence. Work attitude and digital mindset are part of the competencies that are currently needed and sought by employers from new graduates to work well. And the last factor that can be seen from fresh graduates related to work readiness is a readiness in selecting employees. During this pandemic, almost all companies choose employees through online media. Almost all fresh graduates feel that the selection and recruitment done at home via online is becoming more informal and doing things that shouldn't be done. The company or recruiter concludes that they are not well prepared for their job.

For future research, researchers who are interested in work readiness variables are to examine more deeply whether the indicators have been found applicable to all types of work or not. In addition, it is necessary to look for the dynamics of work readiness during the covid pandemic. That future research can add study about work readiness during the pandemic.

\section{REFERENCES}

Aurelia Oktavira S.H, B. (2020). Ketentuan Work from Home ditengah Wabah Pandemi Covid-19.

Bt Mohammad, A. N., Samah, I. H. A., Naiemah, S. U., Rashid, I. M. A., Mansor, M. F., Basri, H. H., \&

Proceedings homepage: https://conferenceproceedings.ump.ac.id/index.php/pssh/issue/view/7 
Nurshahrizleen, S. (2020). Job satisfaction, training \& development, and work environment on career adaptability among fresh graduates in Malaysia. Journal of Critical Reviews, 7(16), 929-934. https://doi.org/10.31838/jcr.07.16.119

Caballero, C., Walker, A., \& Fuller-Tyszkiewicz, M. (2011). The Work Readiness Scale. Journal of Teaching and Learning for Graduate Employability Employability, 2(2), 41-5441.

Caballero, C. L., \& Walker, A. (2010). Work readiness in graduate recruitment and selection: A review of current assessment methods. Journal of Teaching and Learning for Graduate Employability, 1(1), 13. https://doi.org/10.21153/jtlge2010vol1no1art546

Charmaz, Kathy. (2006). Constructing grounded theory: A practical guide through qualitative analysis. Thousand Oaks: SAGE Publications.

Clark, H. (2013). Work Readiness Standards and Benchmarks: The Key to Differentiating America's Workforce and Regaining Global Competitiveness. Act, 1-20.

Engward, H. (2013). Understanding grounded theory. Nursing Standard. 28(7), 37-41. https://doi.org/10.7748/ns2013.10.28.7.37.e7806

Halim, M., Jamilah, R., Adindo, A. W., \& Safaruddin, L. (2019). The Effect of Work Motivation and Industrial Work Practices on The Readiness of Work Students in Class XII Accounting Department of SMK Negeri 1 Kendari. International Journal of Education and Research, 7(12), 25-34.

Jalil, Abdul, M, fahri, \& kasnelly, sri. (2020). Meningkatnya Angka Pengangguran Di Tengah Pandemi (Covid-19). 2(pengangguran akibat covid 19), 45-60.

Jollands, M., Jolly, L., \& Molyneaux, T. (2012). Project-based learning as a contributing factor to graduates' work

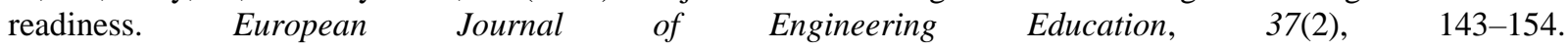
https://doi.org/10.1080/03043797.2012.665848

Kaplan, M., \& Kaplan, A. (2018). The Relationship between Organizational Commitment and Work Performance: a Case of Industrial Enterprises. Journal of Economic and Social Development (JESD), 5(1), 46-50. Retrieved from http://www.jesd-online.com/dokumenti/upload/separated/Vol_5_No_1_Paper5.pdf

Krishnan, I. A., Ramalingam, S. J., Ching, H. S., \& Maruthai, E. (2017). The selection practices and recruitments of fresh graduates in local organization's job interview. Journal of Language and Communication, 4(2), 153-167.

Makki, B. I., Javaid, M. U., \& Bano, S. (2016). Level of Work Readiness Skills, Career Self-Efficacy and Career Exploration of Engineering Students. NFC-IEFR Journal of Engineering and Scientific Research, 4(1), 91-96. https://doi.org/10.24081/nijesr.2016.1.0017

Mustikawanto, A. (2019). Effect of Competency, Work Motivation, Industrial Work Experience and Facilities on the Readiness of Work for Senior High School Graduates in Electro Expertise Programs. Innovation of Vocational Technology Education, 15(1), 1. https://doi.org/10.17509/invotec.v15i1.16045

Nadella, N., \& Rahadi, D. R. (2020). Pengembangan Kompetensi Di Masa Pandemi COVID 19. INOBIS: Jurnal Inovasi Bisnis Dan Manajemen Indonesia, 4(1), 72-83. https://doi.org/10.31842/jurnalinobis.v4i1.167

Pang, E., Wong, M., Leung, C. H., \& Coombes, J. (2019). Competencies for fresh graduates' success at work: Perspectives of employers. Industry and Higher Education, 33(1), 55-65. 
https://doi.org/10.1177/0950422218792333

Prikshat, V., Kumar, S., \& Nankervis, A. (2019). Work-readiness integrated competence model: Conceptualisation and scale development. Education and Training, 61(5), 568-589. https://doi.org/10.1108/ET-05-2018-0114

Purnawan, P., Santosa, B., \& Kurniawan, A. (2020). Automotive Vocational High School: How Career Guidance and Parents Support Impact the Students' Work Readiness. Journal of Vocational Education Studies, 3(1), 61. https://doi.org/10.12928/joves.v3i1.2142

Serhan, C., Tsangari, H., Bengoa, D. S., \& Mekdessi, S. (2015). Fresh graduates' retention: A review of the literature. IOSR Journal of Business and Management, (February). https://doi.org/10.9790/487X-18225164

Strauss, A., \& Corbin, J. (1997). Grounded Theory in Practice. California: SAGE Publications.

Verma, P., Sanjeev, K., \& Alan, N. (2019). Work-readiness integrated competence model: Conceptualisation and scale development. Education + training, 61(5), 568-589. https://doi.org/10.1108/ET-05-2018-0114

Walker, A., \& Campbell, K. (2013). Work readiness of graduate nurses and the impact on job satisfaction, work engagement, and intention to remain. Nurse Education Today, 33(12), 1490-1495. https://doi.org/10.1016/j.nedt.2013.05.008

Wirianata, H. (2017). Kompetensi Mahasiswa Jurusan Akuntansi Dan Kesiapannya Dalam Menghadapi Dunia Kerja Era Masyarakat Ekonomi Asean (Mea). Jurnal Ekonomi, 22(3), 448-465. https://doi.org/10.24912/je.v22i3.278 